\title{
Systematic review of intervertebral disc repair: a bibliometric analysis of the 100 most-cited articles
}

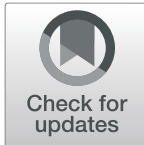

\author{
Gang $\mathrm{Xu}^{1}$, Xianglong Meng ${ }^{1 *}$, Juan Guan², Yaozhong Xing ${ }^{1}$, Zihe Feng ${ }^{1}$ and Yong Hai ${ }^{1}$
}

\begin{abstract}
Study design: A bibliometric review of the literature.

Objective: To identify the most frequently cited articles relating to the repair of intervertebral disc (IVD) and to summarize the key points and findings of these highly cited works, to quantify their impact on the developments of the disc disease treatment.

Summary of background data: IVD repair is an ever-growing and multi-disciplinary innovating treatment method for disc diseases. There are numerous literatures and related studies about it, promoting the development of the field. A comprehensive review and analysis of the most influential articles can help clarify the most effective strategy of IVD repair, and discover the promising directions for future research.

Methods: The Thomson Reuters Web of Knowledge was searched for citations of all literatures relevant to IVD repair. The number of citations, key points, categories, authorships, years, journals, countries, and institutions of publications were analyzed.
\end{abstract}

Results: The most highly cited articles in IVD Repair were published over 30 years, between 1991 and 2017. Most works (No. 41) were published between 2005 and 2009. The most-cited article was Sakai's 2003 article which described the possibility of combining MSC and gel to repair IVD. The three most popular categories involved were Orthopedics [44], Clinical Neurology [34], Engineering, and Biomedical [24]. The three most common topics were regenerative medicine and the progenitor cells [33], biomaterials and cellular scaffolds [29], application of growth factors [25]. Author Masuda and the partners have 4 articles in the top 100 list. The Rush University has 12 articles in the top 100 list.

Conclusion: This report identifies the top 100 articles in IVD repair and acknowledges those individuals who have contributed the most to the study of the IVD repair and the body of knowledge used to the repair strategy making. It allows insight into the trends of this innovative and interdisciplinary subspecialty of spine surgery.

\footnotetext{
* Correspondence: mengxianglong99@126.com

'Beijing Chao-yang Hospital, Capital Medical University, 8 Gongren Tiyuchang Nanlu, Chaoyang District, Beijing 100020, China

Full list of author information is available at the end of the article
}

(c) The Author(s). 2021 Open Access This article is licensed under a Creative Commons Attribution 4.0 International License, which permits use, sharing, adaptation, distribution and reproduction in any medium or format, as long as you give appropriate credit to the original author(s) and the source, provide a link to the Creative Commons licence, and indicate if changes were made. The images or other third party material in this article are included in the article's Creative Commons licence, unless indicated otherwise in a credit line to the material. If material is not included in the article's Creative Commons licence and your intended use is not permitted by statutory regulation or exceeds the permitted use, you will need to obtain permission directly from the copyright holder. To view a copy of this licence, visit http://creativecommons.org/licenses/by/4.0/ The Creative Commons Public Domain Dedication waiver (http://creativecommons.org/publicdomain/zero/1.0/) applies to the data made available in this article, unless otherwise stated in a credit line to the data. 


\section{Introduction}

The pain and dysfunction of lumber and lower extremities caused by degenerative disc disease (DDD) are the focus of spinal surgery [1]. However, when conservative treatment fails, aggressive treatment is surgical intervention, such as discectomy, disc replacement and spinal fusion, These treatments can only temporarily relieve pain, cannot restore the normal structure and biomechanical function of the IVD, resulting in the loss of normal function of the corresponding segment, and with a higher postoperative recurrence rate. Driven by biomaterials and tissue engineering, it is possible to construct intervertebral discs in vitro and repair in vivo. The WHO has nominated the development of mesenchymal stem cells and cell scaffold to promote IVD repair as primary research objectives [2]. Recent years, basic sciences and clinical research remain paramount in the understanding and advancement of IVD repair, in which many related literatures have been reported. The disciplines involved, research directions, objectives and main ideas, methods about these studies are different from each other. It is difficult to determine the best engineering strategy that may advance IVD repair. For innovative topics, it is particularly important to find research trends and directions during the important articles.

Bibliometric analysis is a method used to study published articles citation history, which can be used to overcome the evaluation mentioned above [3]. The number of citations received by an article can be used to quantify the influence the work has had in a particular area of investigation [4]. The most highly cited publications represent the highest impact work in a given field and serve as the basic of a new category [5]. The research directions of these articles can show the trends in this research area [6]. The greater the number of citations an author has, the more influence they have in their particular area of expertise [7]. As the impact factor (IF) is considered to be a measure of journal quality and rank, the IF of the journal can be analyzed by citation analysis to evaluate the importance of the journal [8].

In spinal surgery, recent publications identified the top 100 articles about spinal deformity surgery [9], imaging of the spine [10], cervical spine surgery [11], lumbar spine surgery [12], and in spinal journals etc. The goal of this article is to identify the most-cited literatures about IVD repair and to analyze the top 100 of them. They were analyzed around the following parameters: frequency of citation, categories, chronological, geographical, institutional, and journals, as well as the keywords and subject terms involved and their frequency of occurrence. In order to discover the authoritative trends and directions in the research of IVD repair.

\section{Materials and methods}

The Thomson Reuters Web of Knowledge, a search platform that provides bibliographic database services, was used to search for citations of all articles from 1980 to 2019 relevant to the IVD repair. The decision on which journals to search was made with the use of Thomson Reuters Journal Citation Report database, which ranks journals according to impact factor.

The search limits and sorting options in the Thomson Reuters Web of Knowledge were used to rank all articles from each journal according to the number of citations. The results were then carefully reviewed and only those relevant to IVD repair were selected. The 100 articles that matched the search criteria were then further analyzed. Specifically, the title, first author, journal, year of publication, number of citations, origin nations and institutions were recorded.

\section{Result}

A total of 1183 articles matched the search criteria. Of those, 50 were cited more than 100 times. Table 1 demonstrates the top 100 most-cited articles regarding IVD repair. The articles are published between 2000 and 2017 except one is published at 1991, which was written by Thompson and was cited 316 times. The mean number of citations of the selected 100 articles was 112.32 . The most highly cited article was "Transplantation of mesenchymal stem cells embedded in Atelocollagen $((\mathrm{R}))$ gel to the intervertebral disc: a potential therapeutic model for disc" published in the Biomaterials by Sakai et al, with 332 citations on Web Of Science (WOS).Between 2005 and 2009, producing the largest number of highly cited articles published (41\%) (Fig. 1). The top 100 articles were published in 48 journals, with the top 3 journals publishing $44 \%$ of the articles (Table 2). The top journal was Spine, with 23 articles, followed by the Biomaterials, with 9 articles, and the European Spine Journal, with 9 articles. The 3 most popular categories published were Orthopedics (No. is 44), Clinical Neurology (No. is 34), Engineering, Biomedical (No. is 24) (Table 3). A total of 81 first authors contributed to the top 100 articles. Only 2 were credited with 3 or more publications and only 1 , Masuda, had 4 publications in the top 100 (Table 4). The top articles originated from 18 different countries, with the USA (44\%) being the most prolific (Fig. 2). There were 59 institutions responsible for the top-cited articles with Rush University in Chicago, the USA, contributed 12 publications of the top 100 (Table 5).

\section{Discussion}

Bibliometrics is a form of statistical analysis used to quantify the frequency of citations within published academic literature [13]. Although not the sole marker of 
Table 1 The top 100 papers in IVD repair

\begin{tabular}{|c|c|c|c|c|c|}
\hline Rank & Year & First author & Article title & Key-point & $\begin{array}{l}\text { Cited } \\
\text { times }\end{array}$ \\
\hline 1 & 2003 & Sakai, D & $\begin{array}{l}\text { Transplantation of mesenchymal stem cells embedded in Atelocollagen((R)) } \\
\text { gel to the intervertebral disc: a potential therapeutic model for disc } \\
\text { degeneration }\end{array}$ & Mesenchymal Stem Cell (Msc) & 332 \\
\hline 2 & 1991 & Thompson, JP & Stimulation of mature canine intervertebral disc by growth factors & Growth Factor & 316 \\
\hline 3 & 2006 & Sakai, D & $\begin{array}{l}\text { Regenerative effects of transplanting mesenchymal stem cells embedded in } \\
\text { atelocollagen to the degenerated intervertebral disc }\end{array}$ & MSC & 299 \\
\hline 4 & 2004 & Risbud, MV & $\begin{array}{l}\text { Differentiation of mesenchymal stem cells towards a nucleus pulposus-like } \\
\text { phenotype in vitro: implications for cell-based transplantation therapy }\end{array}$ & MSC & 283 \\
\hline 5 & 2011 & Orozco, L & $\begin{array}{l}\text { Intervertebral Disc Repair by Autologous Mesenchymal Bone Marrow Cells: A } \\
\text { Pilot Study }\end{array}$ & MSC & 238 \\
\hline 6 & 2007 & Risbud, MV & $\begin{array}{l}\text { Evidence for skeletal progenitor cells in the degenerate human intervertebral } \\
\text { disc }\end{array}$ & Endogenous Progenitors & 208 \\
\hline 7 & 2008 & Richardson, SM & $\begin{array}{l}\text { Human mesenchymal stem cell differentiation to NP-like cells in chitosan- } \\
\text { glycerophosphate hydrogels }\end{array}$ & $\begin{array}{l}\text { Chitosan-Glycerophosphate } \\
\text { and Msc }\end{array}$ & 202 \\
\hline 8 & 2003 & Alini, M & $\begin{array}{l}\text { The potential and limitations of a cell-seeded collagen/hyaluronan scaffold } \\
\text { to engineer an intervertebral disc-like matrix }\end{array}$ & Scaffold and Cell & 201 \\
\hline 9 & 2004 & Mizuno, $\mathrm{H}$ & $\begin{array}{l}\text { Tissue-engineered composites of anulus fibrosus and nucleus pulposus for } \\
\text { intervertebral disc replacement }\end{array}$ & Novel Materials & 199 \\
\hline 10 & 2004 & Walsh, AJL & In vivo growth factor treatment of degenerated intervertebral discs & Grow Factor & 197 \\
\hline 11 & 2003 & Hunter, CJ & $\begin{array}{l}\text { The notochordal cell in the nucleus pulposus: A review in the context of } \\
\text { tissue engineering }\end{array}$ & Notochordal Cell & 196 \\
\hline 12 & 2003 & Ganey, $T$ & $\begin{array}{l}\text { Disc chondrocyte transplantation in a canine model: A treatment for } \\
\text { degenerated or damaged intervertebral disc }\end{array}$ & Autologous Chondrocyte & 194 \\
\hline 13 & 2007 & Meisel, HJ & $\begin{array}{l}\text { Clinical experience in cell-based therapeutics: Disc chondrocyte transplant- } \\
\text { ation - A treatment for degenerated or damaged intervertebral disc }\end{array}$ & $\begin{array}{l}\text { Autologous Cultured Disc- } \\
\text { Derived Chondrocytes (ADCT) }\end{array}$ & 181 \\
\hline 14 & 2006 & Sontjens, SHM & Biodendrimer-based hydrogel scaffolds for cartilage tissue repair & Hydrogel Scaffold & 169 \\
\hline 15 & 2011 & Smith, LJ & $\begin{array}{l}\text { Degeneration and regeneration of the intervertebral disc: lessons from } \\
\text { development }\end{array}$ & Embryonic Morphogenesis & 167 \\
\hline 16 & 2004 & Masuda, K & Growth factors and treatment of intervertebral disc degeneration & Growth Factor & 166 \\
\hline 17 & 2002 & Kroeber, M & $\begin{array}{l}\text { New in vivo animal model to create intervertebral disc degeneration and to } \\
\text { investigate the effects of therapeutic strategies to stimulate disc } \\
\text { regeneration }\end{array}$ & Factor and Signal & 155 \\
\hline 18 & 2002 & Cs-Szabo, G & $\begin{array}{l}\text { Changes in mRNA and protein levels of proteoglycans of the anulus fibrosus } \\
\text { and nucleus pulposus during intervertebral disc degeneration }\end{array}$ & Proteoglycans & 151 \\
\hline 19 & 2010 & Yoshikawa, $\mathrm{T}$ & $\begin{array}{l}\text { Disc Regeneration Therapy Using Marrow Mesenchymal Cell Transplantation } \\
\text { A Report of Two Case Studies }\end{array}$ & MSC & 149 \\
\hline 20 & 2010 & Richardson, SM & $\begin{array}{l}\text { Mesenchymal Stem Cells in Regenerative Medicine: Opportunities and } \\
\text { Challenges for Articular Cartilage and Intervertebral Disc Tissue Engineering }\end{array}$ & MSC & 147 \\
\hline 21 & 2006 & Chujo, T & $\begin{array}{l}\text { Effects of growth differentiation factor-5 on the intervertebral disc - In vitro } \\
\text { bovine study and in vivo rabbit disc degeneration model study }\end{array}$ & Growth Factor : rhGDF-5 & 146 \\
\hline 22 & 2002 & Roughley, PJ & $\begin{array}{l}\text { The role of proteoglycans in aging, degeneration and repair of the } \\
\text { intervertebral disc }\end{array}$ & Proteoglycan & 142 \\
\hline 23 & 2015 & $\begin{array}{l}\text { Rosenzweig, } \\
\text { DH }\end{array}$ & $\begin{array}{l}\text { 3D-Printed ABS and PLA Scaffolds for Cartilage and Nucleus Pulposus Tissue } \\
\text { Regeneration }\end{array}$ & Hydrogel Scaffold and MSC & 135 \\
\hline 24 & 2008 & Nesti, $\sqcup J$ & $\begin{array}{l}\text { Intervertebral disc tissue engineering using a novel hyaluronic acid- } \\
\text { nanofibrous scaffold (HANFS) amalgam }\end{array}$ & Scaffold & 135 \\
\hline 25 & 2009 & Bron, JL & $\begin{array}{l}\text { Repair, regenerative and supportive therapies of the annulus fibrosus: } \\
\text { achievements and challenges }\end{array}$ & MSC & 134 \\
\hline 26 & 2013 & latridis, JC & $\begin{array}{l}\text { Role of biomechanics in intervertebral disc degeneration and regenerative } \\
\text { therapies: what needs repairing in the disc and what are promising } \\
\text { biomaterials for its repair? }\end{array}$ & Biomechanics & 134 \\
\hline 27 & 2009 & Ganey, $T$ & $\begin{array}{l}\text { Intervertebral Disc Repair Using Adipose Tissue-Derived Stem and Regenera- } \\
\text { tive Cells Experiments in a Canine Model }\end{array}$ & $\begin{array}{l}\text { Adipose Tissue-Derived Stem } \\
\text { and Regenerative Cells (ADRC) }\end{array}$ & 133 \\
\hline
\end{tabular}


Table 1 The top 100 papers in IVD repair (Continued)

\begin{tabular}{|c|c|c|c|c|c|}
\hline Rank & Year & First author & Article title & Key-point & $\begin{array}{l}\text { Cited } \\
\text { times }\end{array}$ \\
\hline 28 & 2007 & Chubinskaya, S & OP-1/BMP-7 in cartilage repair & $\begin{array}{l}\text { BMP-7 and Osteogenic } \\
\text { protein-1(OP-1) }\end{array}$ & 133 \\
\hline 29 & 2011 & Collin, EC & An injectable vehicle for nucleus pulposus cell-based therapy & Hydrogel and ADRC & 129 \\
\hline 30 & 2008 & Masuda, K & $\begin{array}{l}\text { Biological repair of the degenerated intervertebral disc by the injection of } \\
\text { growth factors }\end{array}$ & $\begin{array}{l}\text { Review: Annulus Ribrous } \\
\text { Repair }\end{array}$ & 128 \\
\hline 31 & 2016 & Richardson, SM & $\begin{array}{l}\text { Mesenchymal stem cells in regenerative medicine: Focus on articular } \\
\text { cartilage and intervertebral disc regeneration }\end{array}$ & Growth Factor & 128 \\
\hline 32 & 2005 & Zhang, YG & $\begin{array}{l}\text { Bone mesenchymal stem cells transplanted into rabbit intervertebral discs } \\
\text { can increase proteoglycans }\end{array}$ & MSC & 127 \\
\hline 33 & 2008 & Hohaus, C & Cell transplantation in lumbar spine disc degeneration disease & ADCT & 126 \\
\hline 34 & 2013 & Guterl, CC & $\begin{array}{l}\text { CHALLENGES AND STRATEGIES IN THE REPAIR OF RUPTURED ANNULUS } \\
\text { FIBROSUS }\end{array}$ & Cells, Scaffold and Signal & 126 \\
\hline 35 & 2007 & O'Halloran, DM & Tissue-engineering approach to regenerating the intervertebral disc & Cells, Scaffold and Signal & 119 \\
\hline 36 & 2012 & Pattappa, G & Diversity of intervertebral disc cells: phenotype and function & IVD Cell Phenotype & 117 \\
\hline 37 & 2002 & Takegami, K & $\begin{array}{l}\text { Osteogenic protein-1 enhances matrix replenishment by intervertebral disc } \\
\text { cells previously exposed to interleukin-1 }\end{array}$ & Interleukin-1(IL1a)+OP1 & 115 \\
\hline 38 & 2008 & Ellman, MB & $\begin{array}{l}\text { Biological impact of the fibroblast growth factor family on articular cartilage } \\
\text { and intervertebral disc homeostasis }\end{array}$ & Cell Phenotype and MSC & 114 \\
\hline 39 & 2010 & Strassburg, S & $\begin{array}{l}\text { Co-culture induces mesenchymal stem cell differentiation and modulation of } \\
\text { the degenerate human nucleus pulposus cell phenotype }\end{array}$ & Growth Factor & 114 \\
\hline 40 & 2008 & Wan, YQ & Biphasic scaffold for annulus fibrosus tissue regeneration & Scaffold & 113 \\
\hline 41 & 2001 & Johnson, WEB & $\begin{array}{l}\text { Cell cluster formation in degenerate lumbar intervertebral discs is associated } \\
\text { with increased disc cell proliferation }\end{array}$ & IVD Cell Phenotype & 111 \\
\hline 42 & 2001 & Baer, AE & $\begin{array}{l}\text { Collagen gene expression and mechanical properties of intervertebral disc } \\
\text { cell-alginate cultures }\end{array}$ & PNCA / KI67 & 111 \\
\hline 43 & 2004 & Gorensek, M & $\begin{array}{l}\text { Nucleus pulposus repair with cultured autologous elastic cartilage derived } \\
\text { chondrocytes }\end{array}$ & $\mathrm{ADCT}$ & 105 \\
\hline 44 & 2003 & $\mathrm{An}, \mathrm{HS}$ & Biological repair of intervertebral disc & MSC & 104 \\
\hline 45 & 2007 & Paesold, G & $\begin{array}{l}\text { Biological treatment strategies for disc degeneration: potentials and } \\
\text { shortcomings }\end{array}$ & $\begin{array}{l}\text { Gene Therapy and Tissue } \\
\text { Engineering }\end{array}$ & 103 \\
\hline 46 & 2008 & Korecki, CL & $\begin{array}{l}\text { Needle puncture injury affects intervertebral disc mechanics and biology in } \\
\text { an organ culture model }\end{array}$ & Biomechanic & 102 \\
\hline 47 & 2005 & Perie, D & $\begin{array}{l}\text { Confined compression experiments on bovine nucleus pulposus and annulus } \\
\text { fibrosus: sensitivity of the experiment in the determination of compressive } \\
\text { modulus and hydraulic permeability }\end{array}$ & Biomechanic & 101 \\
\hline 48 & 2009 & McGirt, MJ & $\begin{array}{l}\text { A Prospective Cohort Study of Close Interval Computed Tomography and } \\
\text { Magnetic Resonance Imaging After Primary Lumbar Discectomy Factors } \\
\text { Associated With Recurrent Disc Herniation and Disc Height Loss }\end{array}$ & Lumbar Discectomy & 100 \\
\hline 49 & 2003 & Sato, M & $\begin{array}{l}\text { An atelocollagen honeycomb-shaped scaffold with a membrane seal (ACHM } \\
\text { S-scaffold) for the culture of annulus fibrosus cells from an intervertebral disc }\end{array}$ & Scaffold & 99 \\
\hline 50 & 2005 & Mwale, F & $\begin{array}{l}\text { Biological evaluation of chitosan salts cross-linked to genipin as a cell scaffold } \\
\text { for disk tissue engineering }\end{array}$ & Scaffold & 98 \\
\hline 51 & 2010 & Shen, BJ & $\begin{array}{l}\text { The Role of BMP-7 in Chondrogenic and Osteogenic Differentiation of Hu- } \\
\text { man Bone Marrow Multipotent Mesenchymal Stromal Cells In Vitro }\end{array}$ & BMP-7 and MSC & 97 \\
\hline 52 & 2008 & Wuertz, K & $\begin{array}{l}\text { Behavior of mesenchymal stem cells in the chemical microenvironment of } \\
\text { the intervertebral disc }\end{array}$ & Inflammatory Response & 96 \\
\hline 53 & 2015 & Molinos, M & Inflammation in intervertebral disc degeneration and regeneration & MSC & 96 \\
\hline 54 & 2014 & Huang, YC & OPINION Intervertebral disc regeneration: do nutrients lead the way? & Disc Nutrients Supply & 96 \\
\hline 55 & 2011 & Grunhagen, $T$ & $\begin{array}{l}\text { Intervertebral Disk Nutrition: A Review of Factors Influencing Concentrations } \\
\text { of Nutrients and Metabolites }\end{array}$ & Disc Nutrients Supply & 95 \\
\hline 56 & 2006 & latridis, JC & Effects of mechanical loading on intervertebral disc metabolism in vivo & $\begin{array}{l}\text { Mechanical Loading and Disc- } \\
\text { cell Metabolism }\end{array}$ & 94 \\
\hline
\end{tabular}


Table 1 The top 100 papers in IVD repair (Continued)

\begin{tabular}{|c|c|c|c|c|c|}
\hline Rank & Year & First author & Article title & Key-point & $\begin{array}{l}\text { Cited } \\
\text { times }\end{array}$ \\
\hline 57 & 2002 & Alini, M & $\begin{array}{l}\text { A biological approach to treating disc degeneration: not for today, but } \\
\text { maybe for tomorrow }\end{array}$ & Biomatrix & 93 \\
\hline 58 & 2005 & Kroeber, M & $\begin{array}{l}\text { Effects of controlled dynamic disc distraction on degenerated intervertebral } \\
\text { discs - An in vivo study on the rabbit lumbar spine model }\end{array}$ & In Vivo Model & 93 \\
\hline 59 & 2006 & Akeda, K & $\begin{array}{l}\text { Platelet-rich plasma (PRP) stimulates the extracellular matrix metabolism of } \\
\text { porcine nucleus pulposus and anulus fibrosus cells cultured in alginate beads }\end{array}$ & $\begin{array}{l}\text { Platelet-rich Plasma(PRP) and } \\
\text { Growth Factor }\end{array}$ & 93 \\
\hline 60 & 2009 & Shen, BJ & $\begin{array}{l}\text { BMP-2 Enhances TGF-beta 3-Mediated Chondrogenic Differentiation of Hu- } \\
\text { man Bone Marrow Multipotent Mesenchymal Stromal Cells in Alginate Bead } \\
\text { Culture }\end{array}$ & Disc Distraction & 92 \\
\hline 61 & 2007 & Chang, G & Porous silk scaffolds can be used for tissue engineering annulus fibrosus & Scaffold & 92 \\
\hline 62 & 2010 & Korecki, CL & $\begin{array}{l}\text { Notochordal cell conditioned medium stimulates mesenchymal stem cell } \\
\text { differentiation toward a young nucleus pulposus phenotype }\end{array}$ & $\begin{array}{l}\text { NC and MSC for NP Cell } \\
\text { Phenotype }\end{array}$ & 91 \\
\hline 63 & 2006 & Boyd, LM & $\begin{array}{l}\text { Injectable biomaterials and vertebral endplate treatment for repair and } \\
\text { regeneration of the intervertebral disc }\end{array}$ & Scaffold & 89 \\
\hline 64 & 2007 & Revell, PA & $\begin{array}{l}\text { Tissue engineered intervertebral disc repair in the pig using injectable } \\
\text { polymers }\end{array}$ & Scaffold and MSC & 89 \\
\hline 65 & 2010 & Calderon, L & $\begin{array}{l}\text { TYPE II COLLAGEN-HYALURONAN HYDROGEL - A STEP TOWARDS A SCAF } \\
\text { FOLD FOR INTERVERTEBRAL DISC TISSUE ENGINEERING }\end{array}$ & Scaffold and MSC & 89 \\
\hline 66 & 2015 & Dimozi, A & $\begin{array}{l}\text { OXIDATIVE STRESS INHIBITS THE PROLIFERATION, INDUCES PREMATURE SENE } \\
\text { SCENCE AND PROMOTES A CATABOLIC PHENOTYPE IN HUMAN NUCLEUS } \\
\text { PULPOSUS INTERVERTEBRAL DISC CELLS }\end{array}$ & Oxidative stress & 88 \\
\hline 67 & 2010 & Kallewaard, JW & Discogenic Low Back Pain & Low Back Pain & 87 \\
\hline 68 & 2005 & Takegami, K & $\begin{array}{l}\text { Osteogenic protein-1 is most effective in stimulating nucleus pulposus and } \\
\text { annulus fibrosus cells to repair their matrix after chondroitinase ABC-induced } \\
\text { in vitro chemonucleolysis }\end{array}$ & $\mathrm{OP}-1$ & 86 \\
\hline 69 & 2011 & Schek, RM & $\begin{array}{l}\text { GENIPIN-CROSSLINKED FIBRIN HYDROGELS AS A POTENTIAL ADHESIVE TO } \\
\text { AUGMENT INTERVERTEBRAL DISC ANNULUS REPAIR }\end{array}$ & Novel Materials & 85 \\
\hline 70 & 2010 & Otsuki, S & $\begin{array}{l}\text { Extracellular sulfatases support cartilage homeostasis by regulating BMP and } \\
\text { FGF signaling pathways }\end{array}$ & Growth factor and Signal & 83 \\
\hline 71 & 2005 & Magne, D & Mesenchymal stem cell therapy to rebuild cartilage & MSC & 83 \\
\hline 72 & 2007 & Imai, Y & $\begin{array}{l}\text { Restoration of disc height loss by recombinant human osteogenic protein-1 } \\
\text { injection into intervertebral discs undergoing degeneration induced by an } \\
\text { intradiscal injection of chondroitinase } A B C\end{array}$ & NC & 79 \\
\hline 73 & 2003 & Hunter, CJ & $\begin{array}{l}\text { The three-dimensional architecture of the notochordal nucleus pulposus: } \\
\text { novel observations on cell structures in the canine intervertebral disc }\end{array}$ & $\mathrm{OP}-1$ & 79 \\
\hline 74 & 2013 & Ellman, MB & Fibroblast growth factor control of cartilage homeostasis & $\mathrm{ADCT}$ and MSC & 78 \\
\hline 75 & 2011 & Purmessur, D & $\begin{array}{l}\text { Notochordal conditioned media from tissue increases proteoglycan } \\
\text { accumulation and promotes a healthy nucleus pulposus phenotype in } \\
\text { human mesenchymal stem cells }\end{array}$ & Growth Factor & 78 \\
\hline 76 & 2011 & Acosta, FL & $\begin{array}{l}\text { Porcine Intervertebral Disc Repair Using Allogeneic Juvenile Articular } \\
\text { Chondrocytes or Mesenchymal Stem Cells }\end{array}$ & MSC & 78 \\
\hline 77 & 2006 & Masuda, K & Prevention of disc degeneration with growth factors & Growth Factor & 75 \\
\hline 78 & 2013 & Frith, JE & $\begin{array}{l}\text { An injectable hydrogel incorporating mesenchymal precursor cells and } \\
\text { pentosan polysulphate for intervertebral disc regeneration }\end{array}$ & Directly Repair & 72 \\
\hline 79 & 2000 & Ahlgren, BD & $\begin{array}{l}\text { Effect of anular repair on the healing strength of the intervertebral disc - A } \\
\text { sheep model }\end{array}$ & $\begin{array}{l}\text { Hydrogel Scaffold and MPC } \\
\text { (mesenchymal precursor cell) }\end{array}$ & 72 \\
\hline 80 & 2006 & Wilda, $\mathrm{H}$ & $\begin{array}{l}\text { In vitro studies of annulus fibrosus disc cell attachment, differentiation and } \\
\text { matrix production on PDLLA/45S5 Bioglass (R) composite films }\end{array}$ & Aggrecan & 69 \\
\hline 81 & 2014 & Sivan, SS & Structure, function, aging and turnover of aggrecan in the intervertebral disc & Composite Film & 69 \\
\hline 82 & 2012 & Whatley, BR & Intervertebral disc (IVD): Structure, degeneration, repair and regeneration & IVD Regeneration & 65 \\
\hline 83 & 2006 & Iwashina, $T$ & $\begin{array}{l}\text { Low-intensity pulsed ultrasound stimulates cell proliferation and } \\
\text { proteoglycan production in rabbit intervertebral disc cells cultured in } \\
\text { alginate }\end{array}$ & Proteoglycan & 63 \\
\hline
\end{tabular}


Table 1 The top 100 papers in IVD repair (Continued)

\begin{tabular}{|c|c|c|c|c|c|}
\hline Rank & Year & First author & Article title & Key-point & $\begin{array}{l}\text { Cited } \\
\text { times }\end{array}$ \\
\hline 84 & 2015 & Tsaryk, R & $\begin{array}{l}\text { Collagen-low molecular weight hyaluronic acid semi-interpenetrating net- } \\
\text { work loaded with gelatin microspheres for cell and growth factor delivery for } \\
\text { nucleus pulposus regeneration }\end{array}$ & Hydrogel & 62 \\
\hline 85 & 2006 & Masuoka, K & $\begin{array}{l}\text { Tissue engineering of articular cartilage with autologous cultured adipose } \\
\text { tissue-derived stromal cells using atelocollagen honeycomb-shaped scaffold } \\
\text { with a membrane sealing in rabbits }\end{array}$ & Scaffold and ATSC & 61 \\
\hline 86 & 2010 & Chang, G & Enhancing annulus fibrosus tissue formation in porous silk scaffolds & Scaffold & 60 \\
\hline 87 & 2013 & Hudson, KD & $\begin{array}{l}\text { Recent advances in biological therapies for disc degeneration: tissue } \\
\text { engineering of the annulus fibrosus, nucleus pulposus and whole } \\
\text { intenrertebral discs }\end{array}$ & Scaffold & 60 \\
\hline 88 & 2004 & Masuda, K & Growth factors and the intervertebral disc & Growth Factor & 58 \\
\hline 89 & 2013 & Francisco, AT & Injectable laminin-functionalized hydrogel for nucleus pulposus regeneration & Hydrogel & 58 \\
\hline 90 & 2012 & Chan, SCW & $\begin{array}{l}\text { Intervertebral disc regeneration or repair with biomaterials and stem cell } \\
\text { therapy - feasible or fiction? }\end{array}$ & Hydrogel and MSC & 58 \\
\hline 91 & 2008 & Abbushi, A & $\begin{array}{l}\text { Regeneration of intervertebral disc tissue by resorbable cell-free polyglycolic } \\
\text { acid-based implants in a rabbit model of disc degeneration }\end{array}$ & PGA(polyglycolic acid) Implant & 58 \\
\hline 92 & 2001 & Pattison, ST & $\begin{array}{l}\text { Regulation of gelatinase-A (MMP-2) production by ovine intervertebral disc } \\
\text { nucleus pulposus cells grown in alginate bead culture by transforming } \\
\text { growth factor-beta(1) and insulin like growth factor-1 }\end{array}$ & $\begin{array}{l}\text { Growth Factor: MMP and TGF- } \\
\beta 1\end{array}$ & 57 \\
\hline 93 & 2011 & Mwale, F & $\begin{array}{l}\text { The efficacy of Link } N \text { as a mediator of repair in a rabbit model of } \\
\text { intervertebral disc degeneration }\end{array}$ & Synthetic Peptides(link N) & 56 \\
\hline 94 & 2009 & $\begin{array}{l}\text { Mavrogonatou, } \\
\mathrm{E}\end{array}$ & $\begin{array}{l}\text { High osmolality activates the G1 and G2 cell cycle checkpoints and affects } \\
\text { the DNA integrity of nucleus pulposus intervertebral disc cells triggering an } \\
\text { enhanced DNA repair response }\end{array}$ & DNA repair & 55 \\
\hline 95 & 2012 & Milani, AH & $\begin{array}{l}\text { Injectable Doubly Cross-Linked Microgels for Improving the Mechanical Prop- } \\
\text { erties of Degenerated Intervertebral Discs }\end{array}$ & Scaffold & 54 \\
\hline 96 & 2013 & Salgado, AJ & Tissue Engineering and Regenerative Medicine: Past, Present, and Future & Scaffold and ADCT & 54 \\
\hline 97 & 2005 & Masuoka, K & $\begin{array}{l}\text { Tissue engineering of articular cartilage using an allograft of cultured } \\
\text { chondrocytes in a membrane-sealed atelocollagen honeycomb-shaped scaf- } \\
\text { fold (ACHMS scaffold) }\end{array}$ & TERM & 54 \\
\hline 98 & 2012 & Vadala, G & Bioactive electrospun scaffold for annulus fibrosus repair and regeneration & Gene and Protein Expression & 53 \\
\hline 99 & 2017 & Dowdell, J & Intervertebral Disk Degeneration and Repair & PRP and Growth Factor & 53 \\
\hline 100 & 2013 & Brisby, $\mathrm{H}$ & $\begin{array}{l}\text { The Presence of Local Mesenchymal Progenitor Cells in Human Degenerated } \\
\text { Intervertebral Discs and Possibilities to Influence These In Vitro: A Descriptive } \\
\text { Study in Humans }\end{array}$ & Scaffold and MSC & 53 \\
\hline
\end{tabular}

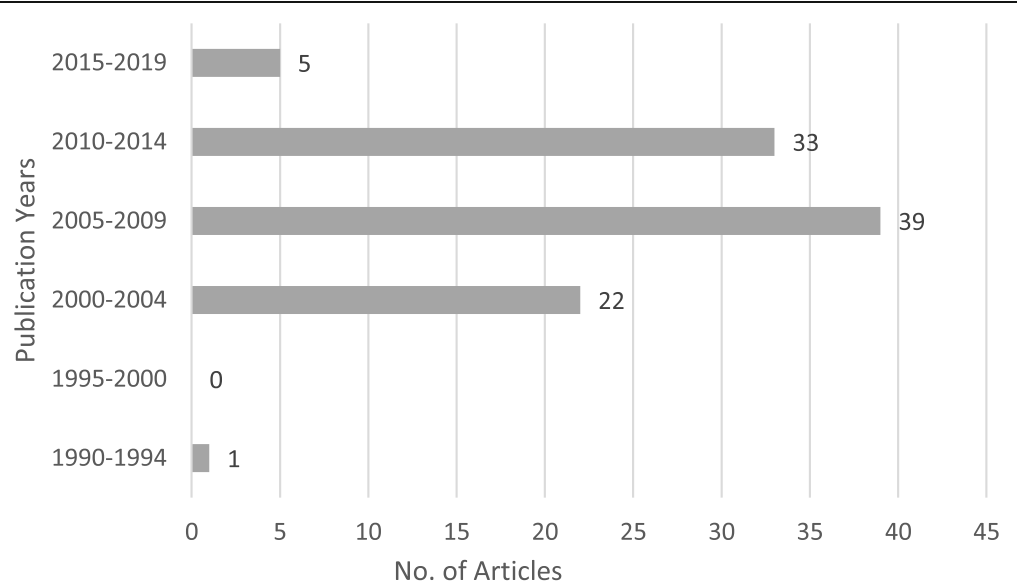

Fig. 1 The 100 most-cited articles related to IVD repair distributed over 5-year intervals according to date of publication 
Table 2 Top journals of publication

\begin{tabular}{lll}
\hline Journal & $\begin{array}{l}\text { No. of } \\
\text { articles }\end{array}$ & $\begin{array}{l}\text { Impact } \\
\text { factor* }\end{array}$ \\
\hline Spine & 23 & 2.903 \\
Biomaterials & 9 & 10.273 \\
European Spine Journal & 9 & 2.513 \\
Tissue Engineering & 6 & 3.508 \\
European Cells \& Materials & 4 & 3.682 \\
Journal of Biomedical Materials Research & 4 & 3.221 \\
Part A & & \\
Arthritis Research \& Therapy & 3 & 4.1418 \\
*As of 2019. & & \\
\hline
\end{tabular}

an articles scientific quality, the number of citations amassed by a paper can be used as a surrogate marker of the impact made within its field.

This article identifies the authors and topics that have made the most impact on the practice of IVD repair over the course of the past 30 years. By identifying these classic works, insight is gained into the history, development, and current trends in IVD repair. The findings of this study identified the articles responsible for the most important developments in this field. Through bibliometrics, we screened the most-cited articles, and we were able to observe that these articles are most often centered around topics that are closely related to tissue engineering regenerative medicine, firstly, the induction of differentiation of stem cells that can achieve maximum restoration of the in vivo structure, so the application of bone marrow mesenchymal stem cells became the most involved topic. Secondly, since the intervertebral disc provides certain biomechanical functions and is a passive load-bearing structure that requires a certain

Table 3 Most popular categories ranked by numbers of articles

\begin{tabular}{ll}
\hline Category & No. of articles \\
\hline Orthopedics & 44 \\
Clinical Neurology & 34 \\
Engineering, Biomedical & 24 \\
Materials Science, Biomaterials & 23 \\
Cell \& Tissue Engineering & 14 \\
Cell Biology & 14 \\
Biochemistry \& Molecular Biology & 13 \\
Surgery & 5 \\
Anatomy \& Morphology & 5 \\
Immunology & 4 \\
Rheumatology & 4 \\
Biochemical Research Methods & 3 \\
Medicine, Research \& Experimental & 3 \\
Genetics \& Heredity & 3 \\
\hline
\end{tabular}

Table 4 Top authors of publication

\begin{tabular}{ll}
\hline Author & No. of articles \\
\hline Masuda, K & 4 \\
Richardson, SM & 3 \\
Risbud, MV & 2 \\
Chang, G & 2 \\
Korecki, CL & 2 \\
Ganey, T & 2 \\
latridis, JC & 2 \\
Mwale, F & 2 \\
Alini, M & 2 \\
Ellman, MB & 2 \\
Hunter, CJ & 2 \\
Kroeber, M & 2 \\
Masuoka, K & 2 \\
Sakai, D & 2 \\
Shen, BJ & 2 \\
Takegami, K & 2 \\
\hline
\end{tabular}

modulus of elasticity and rigidity in different postures, material engineering is particularly important. By controlling the parameters of polymeric synthetic materials, it is possible to find natural or synthetic materials with similar mechanical parameters that will help to meet the required mechanical properties of the disc while stem cells are transplanted. Growth factors play a nonnegligible role in the regulation and induction of the regeneration process, and through the study of growth factors, it is possible to regulate the proliferation and differentiation of stem cells according to the desired parameters. Therefore, articles dealing with these topics are the most cited and the hotspot for research on regenerative repair of intervertebral discs.

The most-cited article in IVD repair is the work in 2003 by Sakai and Mochida [14]; this study showed the hypothesize that the maintenance of proteoglycan content in the disc could be achieved by avoiding the depletion of nucleus pulposus and preserving the structure of the annulus, which is a primary factor of decelerating the disc degeneration, and the stem cell level was the best consideration to solve this problem. They took the rabbits with induced discs degeneration as animal model, which autologous MSCs (mesenchymal stem cells) embedded in Atelocollagen((R)) gel were transplanted into the discs. The results demonstrated that the MSCs transplantation is effective in decelerating disc degeneration. The Atelocollagen $((\mathrm{R}))$ gel served as an important carrier of MSCs in transplantation, permitting proliferation, matrix synthesis and differentiation of MSCs. This idea of combining stem cells with cellular scaffold as a strategy for disc repair is widely used and 


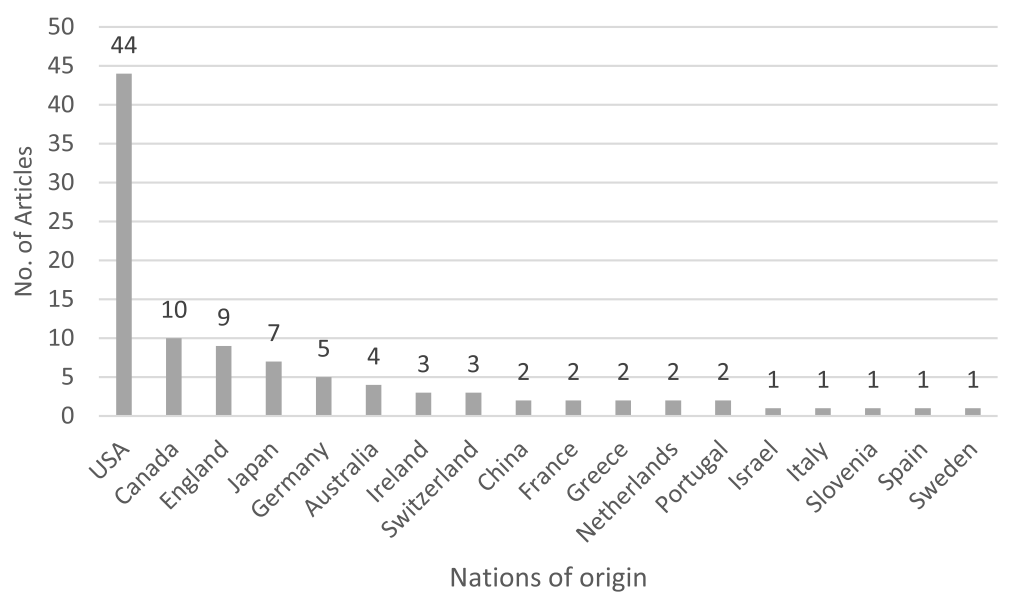

Fig. 2 The nations of origin (according to address provided by the first author) for the 100 most-cited articles

has been shown to be effective. Proteoglycan expression has also become one of the valid indicators for the success of the repair because of the important role it plays in the structure and function of nucleus pulposus and annulus [15].

The second most-cited article is also the oldest in the top 100 list, which is from 1991 by Thompson [16]; this paper describe the stimulation of intervertebral disc by growth factors on mature canine. The study divided the discs into three regions: annular, transitional, and nuclear, and devise a tissue culture system for them. The culture system was perturbed by plasma-derived equine serum, fetal calf serum, insulin-like growth factor-1, epidermal growth factor fibroblast growth factor, and

Table $\mathbf{5}$ Top institutions of origin of articles

\begin{tabular}{ll}
\hline Institution & No. of articles \\
\hline Rush University & 12 \\
McGill University & 5 \\
Icahn School of Medicine at Mount Sinai & 4 \\
University of California & 4 \\
University of Manchester & 4 \\
University of Vermont & 4 \\
Duke University & 3 \\
National Defense medical college & 3 \\
National University of Ireland & 3 \\
Tokai University & 3 \\
BG Hospital Bergmannstrost Halle & 2 \\
Cornell University & 2 \\
Medical Center Atlanta & 2 \\
National center for scientific research "Demokritos" & 2 \\
Thomas Jefferson University & 2 \\
University of Calgary & 2 \\
\hline
\end{tabular}

transforming growth factor-beta. They finally found the transforming growth factor- $\beta$ and epidermal growth factor elicited the greater proliferative response than fibroblast growth factor, more than that, the nucleus and transition zone responded more than anulus to the growth factors. This classic work laid the foundation for growth factors and cell biology in disc repair. More profound and direct evidence of the prominent role of transforming factor- $\beta$ in stimulating the proliferation and differentiation of disc cells has been provided in numerous studies since then and inspired us to consider adding and loading growth factors to play an important assist role while performing stem cell scaffold to repair discs.

The third most-cited article was the 2006 work of Sakai and Mochida [17]. They transplanted the LacZ expressing MSCs to rabbit IVDs 2 weeks after induction of degeneration. Unlike the study reported in 2003, this experiment set up two control groups, including normal controls (NC) without operations and sham operated with only disc degeneration being induced. Then, the disc height by plain radiograph, T2-weighted signal intensity in MRI, histology, immunohistochemistry and matrix-associated gene expressions were evaluated between them. The results confirmed that the MSC group showed an absolute advantage over the other two groups in terms of preservation of disc structure and accumulation of proteoglycans. Therefore, demonstrated MSCs could serve as a valuable resource in cell transplantation therapy for IVD disease. MSC research in tissue engineering for disc repair is a landmark development in this topic, which has led to the involvement of regenerative medicine in the repair of discs where the shortcomings of conventional sutures and simple resection are compensated by the biological effects of MSC. IN the 100 most-cited articles, 21 were related to MSC. Through observation, there have also been many articles 
attempting to repair discs through other types of progenitor cells, such as autologous cultured disc-derived chondrocytes (ADCT).

Regenerative medicine and the application of stem cells was the most popular topic in the top 100 articles with a total of 34 works dedicated to it. In the past exploration of stem cell regeneration for the treatment of disc defects, stem cell attempts began with ADCT, some studies have shown it contribute to the repair of discs, but there are significant limitations in its application, due to the utility of such cells was limited by the difficulties with graft procurement, harvest site morbidity, and functionality [18]. There are 7 articles on ADCT. The most important article was the study by Ganey in 2003, demonstrated that the autologous chondrocyte transplantation is technically feasible and biologically relevant to repairing disc damage and retarding disc degeneration. Afterwards, the focus of progenitor cell selection shifts to the application of MSC (mesenchymal stem cells). The number of articles on MSC applications was largest, nearly 22 papers. MSCs contain stem cells and possess the ability to regenerate bone, cartilage, and fibrous tissues. The studies were broadly divided into vitro culture tests and in vivo degenerative model intervention tests. MSCs were loaded into the disc environment in a variety of ways, including direct injection, loading via cellular scaffolds, etc. After a few weeks, the height of the intervertebral gap was assessed by X-ray, disc water content was assessed by T2-weighted term of MRI, the proteoglycan and collagen content was assessed by proteomics. The majority of trials have confirmed that MSC has excellent results in repairing intervertebral disc defects, restoring disc structure and function, and potentially delaying disc degeneration [14]. The most influential between the 22 articles, already mentioned above, was written by Sakai and Mochida. The strategy was MSCs and Atelocollagen $((\mathrm{R}))$ gel to decelerate the disc degeneration. In addition to this, there are many studies exploring the application of other progenitor cells in intervertebral disc repair, with 3 out of 100 articles studied the adipose tissue-derived stem cells. The repair of a damaged disc is possible using autologous adipose tissue derived stem and regenerative cells (ADRCs), and three out of 100 articles addressed the application of notochordal cell (NC) has also been found contributes to the phenotypic differentiation of MSC towards nucleus pulposus (NP) [19].

The second most popular topic out of the 100 articles was Biomaterials and Cellular Scaffolds, which conducted by 31 articles. Biomolecular materials can be used to repair defects in the fibrous ring and medullary nucleus, restore the biomechanical structure and function of the intervertebral disc, and serve as a carrier for loading delivery cells in the cell therapy process, enhancing the effect of progenitor cells regeneration therapy and drug-assisted therapy such as growth factors. Among the 100 articles analyzed, the most used material is hydrogel, which is used by 11 articles. This exhibits the following properties: (1) it is highly plastic and can be used to repair irregular disc defects; (2) it can be synthesized to include sensitive components such as photosensitive components and temperature-sensitive components; and would undergo structural changes through environmental changes, which can help ensure the biomechanical support of the defect site after repair while filling and repairing; these properties make hydrogel one of the most common choices of cellular scaffold materials. Hydrogel plays a different role in the repair of different parts of the intervertebral disc. It has been demonstrated that hydrogels are superior in restoring the structure of the nucleus. In contrast, the role of hydrogels in annulus fibrous repair is still being explored due to the special laminar structure and the higher intensity biomechanical requirements of it. The most-cited article for hydrogel applications was published by Richardson in 2008, which described the trend of human MSC differentiation towards NP cells on chitosan-glycerophosphate hydrogels. In annulus fibrous repair, many attempts have been made in previous studies, such as silk [20], ABS and PLA Scaffold [21], and a cell scaffold made by chitosan salts crosslinked to Genipin [22].

The third most common topic published in the top 100 IVD repair articles was application of growth factors in IVD regenerative therapy. There are 26 articles related to it. The most-cited article is still the classic 1991 article by Thompson, already mentioned above. A significant role of TGF- $\beta$ in disc regeneration was confirmed in subsequent explorations. In addition, studies have focused on the role of factors such as interleukin-1 (IL-1), osteogenic protein-1 (OP-1), and bone morphogenetic protein-7 (BMP-7).

The most recent article, published in 2017, was written by Dowdell [23]; it is a review about intervertebral disk degeneration and repair, which described the biological therapies as a promising treatment modality for DDD that could impact our future management of low back pain. The 100th article on the list written by Coric et al. [24] is a 12-month prospective cohort of the clinical and radiographic results from a study of cell-based therapy in the treatment of lumbar spondylosis with mechanical LBP.

Among the top-cited articles, 41 papers are published between 2005 and 2009. Unlike the bibliometric analysis of other topics, the most-cited articles are not focused 
on the early part of the chronological range of distribution, as regeneration and tissue repair of the disc are emerging research directions. It is reasonable to speculate that the reason for the sudden burst of high-quality research in IVD repair between the specific time interval is closely related to the breakthrough in regenerative medicine and tissue engineering research. At the same time, we are forced to consider a phenomenon in the bibliometric analysis, called "obliteration by incorporation," which suggests that many classic articles will be cited by later HF-cited articles, which may be one reason why the chronological distribution of HF-cited articles presents the current results.

The journal with the most published articles is SPINE, and although disc repair involves multiple subject areas, it can be found that research dedicated to this direction still revolves around the treatment of spinal disorders, indicating a vision in disc repair to help provide solutions for more patients with low back pain.

To the current authors' knowledge, this article is the first to identify the 100 articles in IVD repair. This study provides unique insight into the development and trends of this challenging subspecialty within Spine Surgery and Regenerative Medicine in the twentieth and early twenty first centuries. The work identifies topics that were involved most into the ever-growing body of knowledge. Furthermore, we can preliminarily identify research trends in the field of IVD repair at the disciplinary level, and preliminarily identify preferred strategies for IVD repair based on up to three topics involved, as a way of collaborative research in multiple disciplinary areas such as progenitor cell tissue engineering, biomaterials and cellular molecular therapy. The field of stem cells and tissue regeneration is dominated by MSC research, combined with multiple comparative progenitor cell studies. The choice of cellular scaffold material is based on the preparation of hydrogels, and the research of natural materials such as silkworm also foreshadows the current and future research attempts. There is a long history of research on proteins such as growth factors that contribute to IVD repair, and synergistic stem cell therapy will help differentiate the different components of the disc. In addition to this, studies of IVD biomechanics as well as tissue embryology are of particularly importance and will help to select cellular scaffold materials with more complex intervertebral mechanics requirements, and explore the possibility of inducing progenitor cell intervertebral differentiation into annulus fibrous and NP (Fig. 3).

In the process of disc repair, combined with the latest concepts of translational medicine [25], it can be envisaged to work together on a disc repair strategy that meets human needs through interdisciplinary research, and to test the performance of the disc with the help of in vitro tests that simulate the biomechanical environment of the disc in vivo, and to prepare patches according to the operational strategy of clinical disc surgery, analyze the in vivo degradation rate of cellular scaffolds and the differentiation of progenitor cells. The rate of filling and the status of the disc patches were assessed by MRI for follow-up assessment at different postoperative time points. This is fed back to the basic laboratory for parameter adjustment by mechanics, regeneration, and structural recovery in the respective disciplinary laboratories. With regard to possible complications in the post-repair period, timely remediation or revision surgery is performed according to the translational medicine strategy, and it is believed that the regenerative disc

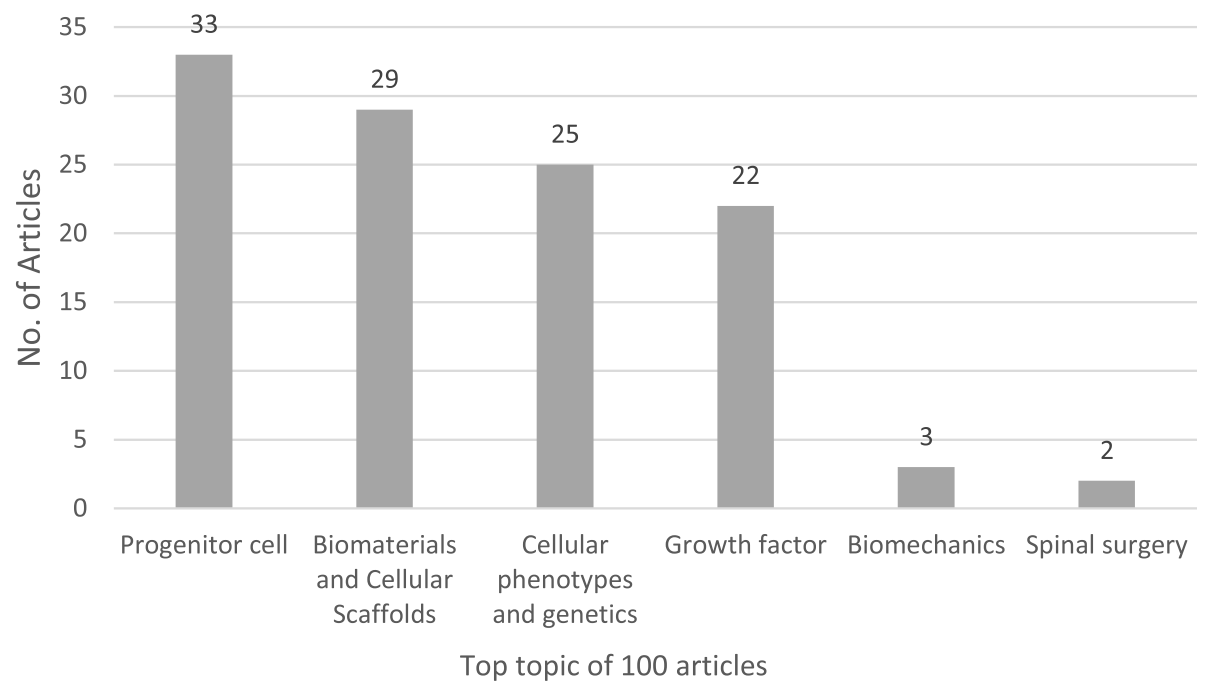

Fig. 3 The top topics for the 100 most-cited articles pertaining to IVD repair 
repair strategy will be applied earlier in the clinical setting through the translational medicine pathway.

\section{Conclusions}

To the best of our knowledge, this study is the first to identify the top 100 classic articles in IVD repair. This study provides a unique insight into the developments and trends in this challenging new spine surgery subspecialty in the early twentieth and twenty first centuries. This work identifies those individuals, institutions, and countries that have contributed most to the growing body of knowledge, and these past study ideas and disc repair strategies suggest that tissue engineering repair of intervertebral disc is an interdisciplinary research topic involving orthopedics, tissue engineering, biomaterials, such as biochemistry and molecular biology, as well as guiding the future direction of disc repair research. In addition, the 100 articles identified in this study are the most-cited articles, the most influential in the field, and the most memorable. It is reasonable to believe that the regenerative repair of the intervertebral disc will be achieved through the efforts of regenerative medicine, discovering the most appropriate progenitor cells for induction, simulating the microenvironment for the regeneration of intervertebral disc cells with growth factors, combining mechanical simulation with material engineering, preparing cellular scaffolds conforming to the mechanical properties of the fibrous ring and nucleus pulposus using materials such as silk proteins and hydrogels, and exploring in depth the induced changes in physical traits.

\section{Abbreviations \\ IVD: Intervertebral disc; DDD: Degenerative disc disease; WOS: Web of Science; NP: Nucleus pulposus; LBP: Low back pain; HF: High frequency; MSC: Mesenchymal stem cells; ABS: Acrylonitrile butadiene styrene copolymer; PLA: Polylactic acid; NC: Notochordal cell; IL-1: Interleukin-1; OP- 1: Osteogenic protein-1 (OP-1); BMP-7: Bone morphogenetic protein-7; ADRC: Autologous adipose tissue-derived stem and regenerative cells; ADCT: Autologous cultured disc-derived chondrocytes; IF: Impact factor; TGF- $\beta$ : Transforming growth factor- $\beta$; WHO: World Health Organization}

\section{Acknowledgements}

Prof. Meng assisted in editing and revising the article. Prof. Guan and Prof. Hai provide directional advice. Mr. Xing and Mr. Feng assisted with data collection and statistical analysis.

\section{Authors' contributions}

This article is co-authored by the authors mentioned. The main work was done by the first author, Gang $\mathrm{Xu}$, and was directed and revised by the corresponding author, Xianglong Meng, with additional work done by the remaining authors. All authors read and approved the final manuscript.

\section{Funding}

We have not received payment or support in kind for any aspect of the submitted work (including but not limited to grants, consulting fee or honorarium, support for travel to meetings for the study or other purposes, fees for participation in review activities such as data monitoring boards, statistical analysis, end point committees, and the like, payment for writing or reviewing the manuscript, provision of writing assistance, medicines, equipment, or administrative support) at any time.

\section{Availability of data and materials}

The data collected and analyzed in the article are from WOS, an open access database of scholarly articles, and are properly adopted and collected.

\section{Ethics approval and consent to participate}

This article does not involve animal or human testing, the use of devices, drugs, novel biomaterials or any experimental interventions, and is based on the analysis and discussion of previous relevant literature, relevant data and citations are cited from public open databases. The literature search and data collection were performed by two authors, with one author performing the search and data collection and the other author performing the quality control, making the evidence reliable.

\section{Consent for publication}

The author grants permission for publication of this article to any journal or organization wishing to receive the article.

\section{Competing interests}

We warrant that our submission to the work is original, does not infringe upon, violate, or misappropriate any copyright or other intellectual property rights, or any other proprietary right, contract or other right or interest of any third party, and that he or she has full power to enter into this agreement. Neither this work nor a similar work has been published nor shall be submitted for publication elsewhere while under consideration by this publication.

\section{Author details}

'Beijing Chao-yang Hospital, Capital Medical University, 8 Gongren Tiyuchang Nanlu, Chaoyang District, Beijing 100020, China. ${ }^{2}$ International Research Center for Advanced Structural and Biomaterials, School of Materials Science and Engineering, Beihang University, Beijing 100191, China.

Received: 10 December 2020 Accepted: 14 February 2021

Published online: 22 March 2021

\section{References}

1. Diebo BG, et al. Adult spinal deformity. Lancet. 2019;394:160-72. https://doi. org/10.1016/S0140-6736(19)31125-0.

2. Melrose J. Strategies in regenerative medicine for intervertebral disc repair using mesenchymal stem cells and bioscaffolds. Regen Med. 2016;11(7):705-24.

3. Kelly JC, et al. The 100 classic papers of orthopaedic surgery: a bibliometric analysis. The Journal of bone and joint surgery. British volume. 2010;92(10): 1338-43.

4. Garfield E. The history and meaning of the journal impact factor. JAMA. 2006; 295(1):90-3.

5. Ellegaard O, Wallin JA. The bibliometric analysis of scholarly production: How great is the impact? Scientometrics. 2015;105(3):1809-31.

6. Roldan-Valadez E, et al. Current concepts on bibliometrics: a brief review about impact factor, Eigenfactor score, CiteScore, SCImago Journal Rank, SourceNormalised Impact per Paper, H-index, and alternative metrics. Irish journal of medical science. 2019;188(3):939-51.

7. Cooper ID. Bibliometrics basics. Journal of the Medical Library Association : JMLA. 2015;103(4):217-8.

8. Garfield, E., Journal impact factor: a brief review. CMAJ, 1999. 161(8): p. 979-980.

9. Skovrlj B, et al. The 100 Classic Papers in Spinal Deformity Surgery. Spine deformity. 2014;2(4):241-7.

10. Das JP, Aherne E, Kavanagh E. Imaging of the spine: a bibliometric analysis of the 100 most-cited articles. Spine. 2019;44(22):1593-8.

11. Skovrlj B, et al. The 100 Most Influential Articles in Cervical Spine Surgery. Global spine journal. 2016;6(1):69-79.

12. Steinberger J, et al. The top 100 classic papers in lumbar spine surgery. Spine. 2015:40(10):740-7.

13. Garfield E. 100 citation classics from the Journal of the American Medical Association. JAMA. 1987:257(1):52-9.

14. Sakai D, et al. Transplantation of mesenchymal stem cells embedded in Atelocollagen((R)) gel to the intervertebral disc: a potential therapeutic model for disc degeneration. Biomaterials. 2003:24(20):3531-41.

15. Roughley PJ, Alini M, Antoniou J. The role of proteoglycans in aging, degeneration and repair of the intervertebral disc. Biochemical Society Transactions. 2002;30:869-74

16. Thompson JP, Oegema TR Jr, Bradford DS. Stimulation of mature canine intervertebral disc by growth factors. Spine. 1991;16(3):253-60. 
17. Sakai $D$, et al. Regenerative effects of transplanting mesenchymal stem cells embedded in atelocollagen to the degenerated intervertebral disc. Biomaterials. 2006;27(3):335-45.

18. Acosta FL Jr, et al. Porcine Intervertebral Disc Repair Using Allogeneic Juvenile Articular Chondrocytes or Mesenchymal Stem Cells. Tissue Engineering Part A. 2011;17(23-24):3045-55.

19. Korecki $\mathrm{CL}$, et al. Notochordal cell conditioned medium stimulates mesenchymal stem cell differentiation toward a young nucleus pulposus phenotype. Stem Cell Research \& Therapy. 2010;1.

20. Chang G, et al. Porous silk scaffolds can be used for tissue engineering annulus fibrosus. European Spine Journal. 2007;16(11):1848-57.

21. Rosenzweig DH, et al. 3D-Printed ABS and PLA Scaffolds for Cartilage and Nucleus Pulposus Tissue Regeneration. International Journal of Molecular Sciences. 2015;16(7):15118-35.

22. Mwale F, et al. Biological evaluation of chitosan salts cross-linked to genipin as a cell scaffold for disk tissue engineering. Tissue Engineering. 2005;11(1-2): 130-40.

23. Dowdell J, et al. Intervertebral Disk Degeneration and Repair. Neurosurgery. 2017:80(3):S46-54.

24. Coric D, et al. Prospective study of disc repair with allogeneic chondrocytes Presented at the 2012 Joint Spine Section Meeting Clinical article. Journal of Neurosurgery-Spine. 2013;18(1):85-95.

25. Mediouni M, Schlatterer D R, Madry H, et al. A review of translational medicine. The future paradigm: how can we connect the orthopedic dots better? Current Medical Research \& Opinion, 2017, 34(7):1.

\section{Publisher's Note}

Springer Nature remains neutral with regard to jurisdictional claims in published maps and institutional affiliations.

Ready to submit your research? Choose BMC and benefit from:

- fast, convenient online submission

- thorough peer review by experienced researchers in your field

- rapid publication on acceptance

- support for research data, including large and complex data types

- gold Open Access which fosters wider collaboration and increased citations

- maximum visibility for your research: over $100 \mathrm{M}$ website views per year

At $\mathrm{BMC}$, research is always in progress.

Learn more biomedcentral.com/submissions 